\title{
Solovievaia nomen novum for Ovatella Solovieva pre-occupied and revision of this fossil Foraminifera (Fusulinida, Profusulinellidae)
}

\author{
Daniel Vachard and François Le Coze
}

\begin{abstract}
The name Ovatella Solovieva in Rauzer-Chernousova, Bensh, Vdovenko, Gibshman, Leven, Lipina, Reitlinger, Solovieva, and Chediya, 1996, is pre-occupied by the gastropod Ovatella Bivona Bernardi, 1832. It is replaced here by Solovievaia Vachard and Le Coze nomen novum. Following this nomenclatural modification, a revision of this profusulinellid genus is proposed.
\end{abstract}

Daniel Vachard. 1 rue des Tilleuls, 59152 Gruson, France; daniel.vachard@free.fr François Le Coze. World Foraminifera Database, 80 rue Jean Parot, 42100 Saint-Etienne, France; francois.lecoze@9online.fr

Keywords: Foraminifera; Fusulinida; new genus name; early Moscovian; palaeobiogeography

Submission: 16 February 2018 Acceptance: 29 May 2018

\section{INTRODUCTION}

The genus name Ovatella Solovieva in Rauzer-Chernousova, Bensh, Vdovenko, Gibshman, Leven, Lipina, Reitlinger, Solovieva, and Chediya, 1996, (Foraminifera Fusulinida) being pre-occupied is replaced herein by Solovievaia Vachard and Le Coze nomen novum. The genus is briefly characterized and analysed.

\section{SYSTEMATIC TAXONOMY}

Phylum FORAMINIFERA d'Orbigny, 1826

Class FUSULINATA Fursenko, 1958 nom. correct. Vachard, Krainer, and Lucas, 2013

Subclass FUSULINANA Fursenko, 1958 nom. translat. Vachard, Pille, and Gaillot, 2010

Order FUSULINIDA Fursenko, 1958

Suborder FUSULININA Wedekind, 1937 nom. correct. Loeblich and Tappan, 1961 emend.

Vachard, 2016

http://zoobank.org/EA1CB1B2-A99A-418B-B50D-DBCA5B4123D4

Vachard, Daniel and Le Coze, François. 2018. Solovievaia nomen novum for Ovatella Solovieva pre-occupied and revision of this fossil Foraminifera (Fusulinida, Profusulinellidae). Palaeontologia Electronica 21.2.20A 1-6. https://doi.org/10.26879/858 https://palaeo-electronica.org/content/2018/2231-solovievaia-nomen-novum 
Superfamily FUSULINOIDEA Möller, 1878 nom. translat. Ciry, 1952 non Miklukho-Maklay, RauzerChernousova and Rozovskaya, 1958

Family PROFUSULINELLIDAE Safonova in Rauzer-Chernousova, Bensh, Vdovenko, Gibshman, Leven, Lipina, Reitlinger, Solovieva, and Chediya, 1996

Solovievaia genus nov.

Nom. nov. pro Ovatella Solovieva in RauzerChernousova, Bensh, Vdovenko, Gibshman, Leven, Lipina, Reitlinger, Solovieva, and Chediya, 1996

zoobank.org/63F9EAC7-E9D1-4C63-9B34-DB2A9E964529

Etymology. Named in honor of the eminent Russian micropaleontologist, a specialist on Carboniferous fusulinids, Maria Nikolaevna Solovieva (1920-1994). The genus is feminine.

Type species. Profusulinella ovata Rauzer-Chernousova, 1938 (Figure 1). According to RauzerChernousova (1938), the holotype and the figured specimens are deposited in the Museum of the Geological Institute, Academy of Sciences, Moscow; holotype, No. 18; figured specimens: No. 19 and 20.

Translated original Russian diagnosis. Type species_Profusulinella ovata Rauser, 1938 (p. 101), Middle Carboniferous, Vereiskiy horizon, Samara Bend, borehole 402, depth 508-511 m. Test ovoid, fairly constant in shape; external whorls with slightly convex sides, internal whorls rounded, truncated or rounded-sharpened. L/D ratio is usually 1.5-1.8 (up to 2.5); number of whorls up to 66.5 ; endothyroid coiling in the first whorls (1-2), uniform in the following whorls; test wall trilayered; septa are planar, in larger forms slightly wavy toward the axial ends; number of septa up to 85 in the fifth whorl; the chomata are usually distinct, rounded, often asymmetrical, less often subquadratic, or weakly developed; the aperture is narrow to moderate, rarely quite wide.

Emended diagnosis. Test involute, ovoid to truncated fusiform, moderately sized, entirely planispiral, or with a short nautiloid juvenarium due to a deviation of the coiling after the second whorl. The lateral slopes are regularly convex. Proloculus spherical and small. Juvenarium of typical aspect among the profusulinellids and schubertelloids ("endothyrid type"). Adult coiling relatively loose. Chambers numerous, wide, and subquadratic. Planar septa in the central parts and only moderately folded near the polar extremities. Chomata generally narrow, low, and asymmetrical. Tunnel narrow to broad, relatively regular. Wall unilayered, darkmicrogranular. Aperture simple, terminal, and basal.

Other species. Profusulinella arta Leontovich in Rauzer-Chernousova et al., 1951; P. arta var. kamensis Safonova in Rauzer-Chernousova et al., 1951; P. carasaica Dzhenchuraeva, 1979; P. cavis Dalmatskaya, 1961; $P$. cavis subsp. arbejalensis van Ginkel, 1965; P. chaohuensis Wang, 1981; $P$. compacta Rumyantseva, 1974; $P$. constans Safonova in Rauzer-Chernousova et al., 1951; $P$. hinodensis Kobayashi, 1994; P. montichomata Sheng and Wang, 1976; P. muruntavica Rumyantseva, 1974; $P$. nuratavensis Solovieva, 1977; $P$. nuratavenis forma longa Dzhenchuraeva, 1979; $P$. omiensis Watanabe, 1973; P. ovata subsp. meridi-
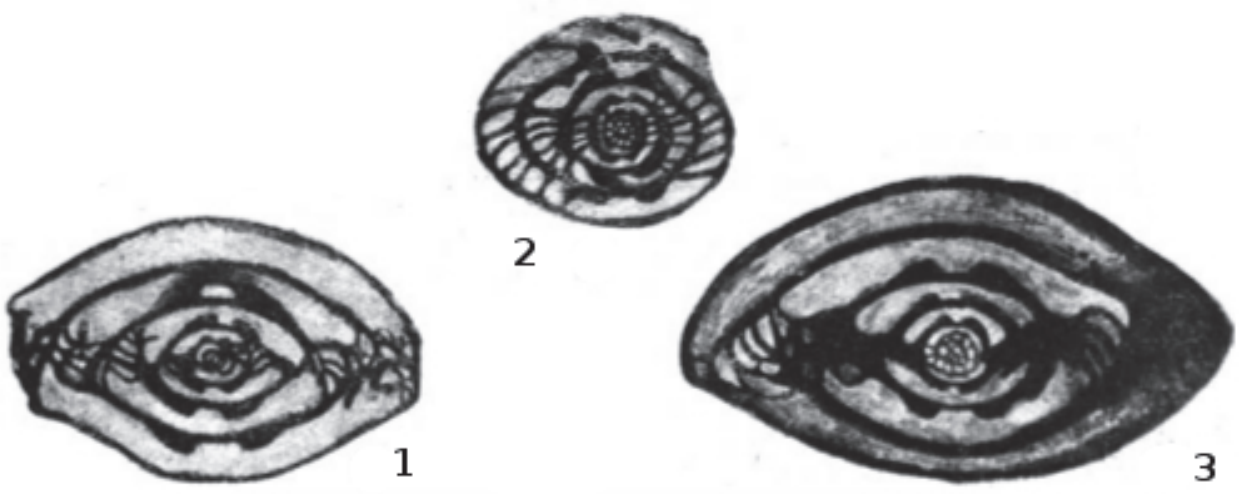

FIGURE 1. Holotype and paratypes of Solovievaia ovata (modified from table 1 of Rauzer-Chernousova, 1938 ). 1. Axial section, Holotype, borehole No. 402, depth 508-511 m, Vereian Horizon (Substage), x 30, specimen No. 18.2. Transverse section, borehole No. 401, depth 543-545 m, Kashirian Horizon, x 30, specimen No. 20. 3. Axial section of a typical specimen, borehole No. 401, depth 584-585 m, Kashirian Horizon, x 30, specimen No. 19. 
ana Bensh, 1969; P. ovata var. nytvica Safonova in Rauser-Chernousova et al., 1951; P. ovata subsp. penduelensis van Ginkel, 1983; $P$. oblonga sensu Ivanova, 1999 non Potievskaya, 1964; Ovatella panjensis Leven, 1998; Neofusulinella praecursor Deprat, 1913; Profusulinella rhombiformis var. ferganensis Bogush, 1963; P. sokolensis Ivanova, 2000; P. subovata Safonova in Rauzer-Chernousova et al., 1951; P. subovata var. bosdonica Rumyantseva, 1974; $P$. tchotchiai Grozdilova and Lebedeva, 1960; and Profusulinella sp. A Igo and Adachi, 1981.

\section{DISCUSSION}

\section{Phylogeny}

Rauzer-Chernousova et al. (1951) identified six groups of species in the genus Profusulinella Rauzer-Chernousova in Rauzer-Chernousova, Belyaev and Reitlinger, 1936: $P$. ovata group; $P$. parva group; $P$. prisca group; $P$. rhomboides group; $P$. librovitchi group; and $P$. mutabilis group. The $P$. rhomboides group, which contains the type species, P. pararhomboidalis Rauzer-Chernousova in Rauzer-Chernousova, Belyaev and Reitlinger, 1936, corresponds, therefore, to Profusulinella sensu stricto. The librovitchi group was first described as another genus under the name Taitzehoella Sheng, 1951. Then, the prisca group was included under the genus Depratina Solovieva in Rauzer-Chernousova et al. (1996) and revised by Kulagina (2009), and the ovata group was included under the genus Ovatella Solovieva in Rauzer-Chernousova et al. (1996). Here, we replace this latter, pre-occupied name by Solovievaia nom. nov.

The true Profusulinella are more rhombic than the Solovievaia and have more developed chomata; they are principally late Bashkirian in age. Depratina is more globular with small chomata and is principally earliest Moscovian (Vereian) in age. Solovievaia is more ovoid and middle to late early Moscovian in age (TsninianKashirian). Taitzehoella is easily differentiated from all these genera by its type of tunnel, aligned and exhibiting a regular increasing in width between symmetrical chomata.

Many species of the parva group (including $P$. parva itself) and some species of the group mutabilis (such as $P$. arta and $P$. arta kamensis) were assigned to Solovievaia/Ovatella by Isakova (2001); this assignment is relatively disputable in relation to the criteria of Rauzer-Chernousova et al. (1951, 1996).

\section{Occurrence}

Early middle Pennsylvanian (middle to late Moscovian) in Western and Central Palaeotethys (northern Spain [Spanish Basque Pyrenees]: Delvolvé et al., 1987; Cantabrian Zone: van Ginkel, 1983; Villa, 1995; southern Turkey: Altiner, 1981; Kobayashi, 2011; Tunisia: Ghazzay-Souli et al., 2015; Iran: Leven and Gorgij, 2011; Darvaz: Leven, 1998); Moscow Basin (Rauzer-Chernousova et al., 1951; Isakova, 2001); the southern, central, and northern Urals (Grozdilova and Lebedeva, 1960; Grozdilova et al., 1975; Malakhova, 1980; Ivanova, 1999, 2000, 2008); Kazakhstan (Marfenkova, 1991); Southwestern Siberia (Bogush, 1963); Uzbekistan (Bensh, 1969; Rumyantseva, 1974; Solovieva, 1977); Kyrgyzstan (Dzhenchuraeva, 1979); Tarim (Zhao et al., 1984); North China (Wang et al., 1992); South China (Shen et al., 1976; Zhang and Rui, 1980; Wang, 1987); northern Thailand (Vachard et al., 1992; Ueno and Igo, 1997), Vietnam (Deprat, 1913; Nguyen Van Liêm, 1967); Laos (Deprat, 1913); and Japan (Watanabe, 1973; Igo and Adachi, 1981; Kobayashi, 1994). In our opinion, the forms of the USA, such as for example Profusulinella marblensis Thompson, 1947, more probably belong to Depratina rather than to Solovievaia/Ovatella sensu stricto (see Kulagina, 2009). Contrary to Solovieva in RauzerChernousova et al. (1996), we infer that Solovievaia is not present in the USA.

\section{CONCLUSION}

Solovievaia is a nomen novum for Ovatella Sosnina, pre-occupied. This genus differs from Depratina and Profusulinella by morphological characters of the test and the coiling. Solovievaia is the more advanced form of the profusulinellid lineages. It appears in the late Vereian, but is particularly common in the Kashirian. Solovievaia probably appeared in the southern Urals due to the continuity of the lineages in this area. Then, it migrated along the entire Urals to Timan, and to the northern border, Perilaurentian, of the Paleotethys from the Basque Pyrenees (France-Spain border) and Cantabrian Zone (northern Spain) to Central Asia (Kyrgystan; Tarim). It has very rarely been mentioned on the southern, Perigondwanan border of the Paleotethys (Tunisia, southern Turkey; and currently was rarely found in Iran). It also migrated to the Eastern Paleotethyan North China, South China and Indonesia blocks, and some Panthalassan localities of Japan, via probably North China. Nevertheless, it is absent from the Ameri- 
cas, both in the northern seaway via connections with the northern Urals, and in the southern seaway in the southern part of USA, Mexico and northern part of South America (e.g., Colombia and Venezuela), where only Depratina and true Profusulinella are known.

\section{ACKNOWLEDGEMENTS}

Thanks to A.B. Doweld for providing several Russian references, and to E. Kulagina and the Editorial Board of Palaeontologia Electronica for their constructive criticisms and advice.

\section{REFERENCES}

Altıner, D. 1981. Recherches stratigraphiques et micropaléontologiques dans le Taurus Oriental au NW de Pinarbaşi (Turquie). Unpublished PhD Thesis, Université de Genève, Geneva, Switzerland.

Bensh, F.P. 1969. Stratigrafiya i foraminifery kammenougolnikh otlozhenii yugo-zapadnykh otrogov i yuzhnogo sklona Gissarskogo khrebta. Izdatelstvo "Fan" Uzbekskoy SSR, Tashkent. (In Russian)

Bivona Bernardi, A. 1832. Caratteri d'un nuovo genere di conchiglie della famiglia delle Plicacee del signor De Lamarck. Effemeridi Scientifiche e Letterarie per la Sicilia, 1:58-59. http:// www.biodiversitylibrary.org/page/10183722

Bogush, O.I. 1963. Foraminifery i stratigrafiya srednego i verkhnego karbona vostochnoy chasti Alaiskogo khrebta. Publishing house of the Academy of Sciences USSR, Moscow. (In Russian)

Ciry, R. 1952. Super-famille 4. Fusulinoidea. p. 179-191. In Piveteau, J. (ed.), Traité de Paléontologie. Masson et Cie, Paris.

Dalmatskaya, I.I. 1961. Stratigrafiya i foraminifery srednekamennougolnikh otlozhenii Gor'kovskogo i Uljanovskogo Povolzhya. Regionalnaya Stratigrafiya SSSR, Izdatelstvo Akademii Nauk SSSR, 5:7-54. (In Russian)

Delvolvé, J.J., Perret, M.F., and Vachard D. 1987. Découverte du Kachirien (Moscovien inférieur) à Fusulines et Algues dans le Massif de Cinco Villas (Pyrénées Basques, Espagne). Geobios, 20:541-548. https://doi.org/10.1016/S0016-6995(87)80087-6

Deprat, J. 1913. Etude des Fusulinidés de Chine et d'Indochine. Les Fusulinidés des calcaires carbonifériens and permiens du Tonkin, du Laos et du Nord-Annam. Mémoires du Service Géologique de l'Indochine, 2:1-74.

d'Orbigny, A. 1826. Tableau méthodique de la classe des Céphalopodes. Annales des Sciences Naturelles, 7:245-314.

Dzhenchuraeva, A.V. 1979. Stratigrafiya i foraminifery srednekammenougolnykh otlozhenii severnykh skolonov Turkestano-Alaya. Izdatelstvo "llim", Akademiya Nauk Kirgizskoi SSR, Frunze. (In Russian)

Fursenko, A.V. 1958. Osnovnye etapy razvitiya faun foraminifer $v$ geologicheskom proshlom. Trudy Instituta Geologicheskikh Nauk, Akademiya Nauk Beloruskoi SSR, 1:10-29. (In Russian)

Ghazzay-Souli, W., Vachard, D., and Razgallah, S. 2015. Carboniferous and Permian biostratigraphy by foraminifers and calcareous algae of Bir Mastoura (BMT-1) and related boreholes of southern Tunisia. Revue de Micropaléontologie, 58:239-265. https://doi.org/ 10.1016/j.revmic.2015.07.004

Grozdilova, L.P. and Lebedeva, N.S. 1960. Foraminifery kamennougolnykh otlozhenii zapadnogo sklona Urala i Timana. Trudy VNIGRI, 150:1-264. (In Russian)

Grozdilova, L.P., Lebedeva, N.S., Lipina, O.A., Malakhova, N.P., Mikhailova, Z.P., Chermnykh, V.A., Postoyalko, M.V., Simonova, Z.G., Sinitsyna, Z.A., and Shcherbakova, M.V. 1975. Foraminifery, p. 27-64. In Stepanov, D.L., Krylova, A.K., Grozdilova, L.P., Pozner, V.M., and Sultanaev, A.A. (eds.), Paleontologicheskii atlas kamennougolnykh otlozhenii Urala. Trudy VNIGRI, 383, Nedra, Leningrad. (In Russian)

Igo, H. and Adachi, S. 1981. Foraminiferal biostratigraphy of the Ichinotani Formation (Carboniferous-Permian) Hida Massif, Central Japan, Part 1: Some foraminifers from the upper part of the Lower Member of the Ichinotani Formation. Science Reports Institute Geosciences, University of Tsukuba, Section B, 2:101-118. 
Isakova, T.N. 2001. Fuzulinidy, p. 1-32. In Alekseev, A.S. and Shik, S.M. (eds.), Srednii karbon Moskovskoy sineklizy (yuzhnaya chast'). Tom 2. Paleontologicheskaya kharakteristika. Nauchnyi Mir, Moscow. (In Russian)

Ivanova, R.M. 1999. Razrez "Sokol" gipostratotip bashkirskogo yarusa srednego karbona na Urale. Materialy po stratigrafii i paleontologii Urala, 2:21-37. (In Russian)

Ivanova, R.M. 2000. Novye vidy foraminifer iz otlozhenii bashkirskogo yarusa (karbon) Yuzhnogo I Srednego Urala, p. 39-44. In Chuvashov, B.I. (ed.), Materialy po stratigrafii i paleontologii Urala, 4. Ural Branch of the Russian Academy of Sciences, Ekaterinenburg. (In Russian)

Ivanova, R.M. 2008. Fuzulinidy i vodorosli srednego karbona Urala (zonalnaya stratigrafiya, paleobiogeografiya, paleontologiya. Ural Branch of the Russian Academy of Sciences, Ekaterinburg.

Kobayashi, F. 1994. Carboniferous foraminifers from the exotic limestone blocks in the Itsukaichi District, southern Kanto Mountains, Japan. Transactions and Proceedings Paleontological Society of Japan, 176:618-637.

Kobayashi, F. 2011. Two species of Profusulinella early Moscovian (Pennsylvanian) fusulines from southern Turkey and subdivision of primitive groups of the family Fusulinidae. Rivista Italiana di Paleontologia e Stratigrafia, 117:29-37. https://doi.org/10.13130/2039-4942/5961

Kulagina, 2009. Evolution of the fusulinid Depratina in the Bashkirian-Moscovian interval. Palaeoworld, 18:94-100. https://doi.org/10.1016/j.palwor.2009.04.003

Leven, E.Ya. 1998. Stratigraphy and Fusulinids of the Moscovian Stage (Middle Carboniferous) in the Southwestern Darvaz (Pamir). Rivista Italiana di Paleontologia e Stratigrafia, 104:3-42. https://doi.org/10.13130/2039-4942/6108

Leven, E.Ya. and Gorgij, M.N. 2011. Fusulinids and Stratigraphy of the Carboniferous and Permian in Iran. Stratigraphy and Geological Correlation, 19:687-776. https://doi.org/ 10.1134/S0869593811070021

Loeblich, A.R. and Tappan, H. 1961. Suprageneric classification of the Rhizopodea. Journal of Paleontology, 35:245-330.

Malakhova, N.P. 1980. Kompleks melkykh foraminifer srednego karbona yugo-vostochnogo Urala. Preprint, Akademiya Nauk SSSR, Uralskii Nauchnyi Tsentr, Trudy Instituta Geologii i Geokhimii, Sverdlovsk. (In Russian)

Marfenkova, M.M. 1991. Morskoi Karbon Kazakhstana. Akademiya Nauk Kazakhskoi SSR, Institut Geologicheskikh Nauk, "Zylym", Alma-Ata. (In Russian)

Miklukho-Maklay, A.D., Rauzer-Chernousova, D.M., and Rozovskaya, S.E. 1958. Sistematika $i$ filogeniya fuzulinidei. Voprosy Mikropaleontologii, 2:5-21. (In Russian; French translation: Editions Technip Paris)

Nguyen Van Liêm, N.V. 1966. New fusulinids from Quy dat, central Vietnam. Acta Scientiarum Vietnamicarum, Sectio Geographicarum et Geologicarum, 1:1-47.

Potievskaya, P.D. 1964. Nekotorye fuzulinidy i melkie foraminifery bashkirskih otlozhenii Bolshogo Donbassa. Trudy IGN AN USSR series stratigraphy and paleontology, 48:31-59. (In Russian)

Rauzer-Chernousova, D.M. 1938. Verkhnepaleozoyskie foraminifery Samarskoy Luki i Zavolzhya. Akademiya Nauk SSSR, Geologichevskii Institut Trudy, 7:69-167. (In Russian)

Rauzer-Chernousova, D.M., Belyaev, G.M., and Reitlinger, E.A. 1936. Verkhnepaleozoiskie foraminifery Pechorskogo Kraya. Trudy Polyarnov Komisii, 28:152-232. (In Russian)

Rauzer-Chernousova, D.M., Bensh, F.R., Vdovenko, M.V., Gibshman, N.B., Leven, E.Ya., Lipina, O.A. Reitlinger, E.A., Solovieva, M.N., and Chediya, I.O. 1996. Spravochnik po sistematike foraminifer Paleozoya; Endothyroidy, Fuzulinoidy. Rossiiskaya Akademiya Nauk, Geologicheskii Institut, Moskva "Nauka", Moscow. (In Russian)

Rauzer-Chernousova, D.M., Gryzlova, N.D., Kireeva, G.D., Leontovich, G.E., Safonova, T.P., and Chernova, E.I. 1951. Srednekamennougolnye fuzulinidy Russkoi platformy i sopredelnykh oblastey. Akademiya Nauk SSR, Institut Geologicheskikh Nauk, Ministerstvo Neftyanoy Promishlennosti SSSR, Moscow. (In Russian)

Rumyantseva, Z.S. 1974. Stratigrafiya i foraminifery srednego Karbona Tsentralnykh Kyzylkumov. Ministerstvo Geologii Uzbeskoi SSR, Sredneaziatskii Nauchno-lssledovatelskii Institut, Geologii i Mineralnogo syrya (Saigims), Izdatelstvo "Fan" Uzbekskoi SSR, Tashkent. (In Russian)

Sheng, J.C. 1951. Taitzehoella, a new genus of fusulinid. Bulletin of the Geological Society of China, 31:79-84. https://doi.org/10.1111/j.1755-6724.1951.mp31001006.x 
Sheng, J., Min, Q., and Wang, L. 1976. Fusulinid zones of the Middle Carboniferous Huanglong Limestone at Jinsigang near Nanjin. Acta Palaeontologica Sinica, 2:196-212, 257-259. (In Chinese with English abstract)

Solovieva, M.N. 1977. Zonalnaya stratigrafiya srednekammenougolnykh otlozhenii SSSR po faune fuzulinatsey. Voprosy Mikropaleontologii, 19:43-67. (In Russian)

Thompson, M.L. 1947. Stratigraphy and fusulinids of pre-Desmoinesian Pennsylvanian rocks, Llano uplift, Texas. Journal of Paleontology, 21:147-164.

Ueno, K. and Igo, H. 1997. Late Paleozoic foraminifers from the Chiang Dao area, northern Thailand. Prace Państwowego Instytutu Geologicznego, 157:339-354.

Vachard, D. 2016. Macroevolution and Biostratigraphy of Paleozoic Foraminifers, p. 257-323. In Montenari, M. (ed.), Stratigraphy \& Timescales, 1. Elsevier, Amsterdam. http://dx.doi.org./ 10.1016/bs.sats.2016.10.005

Vachard, D., Fontaine, H., and Caridroit, M. 1992. Foraminifera, algae and pseudo-algae from Carboniferous and Permian limestones of northwest Thailand. Revue de Paléobiologie, 11:137-147

Vachard, D., Krainer, K., and Lucas, S. 2013. Pennsylvanian (Late Carboniferous) calcareous microfossils from Cedro Peak (New Mexico, USA); Part 2: Smaller foraminifers and fusulinids. Annales de Paléontologie, 99:1-42.https://doi.org/10.1016/j.annpal.2012.08.002

Vachard, D., Pille, L., and Gaillot, J. 2010. Palaeozoic Foraminifera: systematics, palaeoecology and responses to the global changes. Revue de Micropaléontologie, 53:209-254. https:// doi.org/10.1016/j.revmic.2010.10.001

van Ginkel, A.C. 1965. Carboniferous fusulinids from the Cantabrian Mountains (Spain). Leidse Geologische Mededelingen, 34:1-225.

van Ginkel, A.C. 1983. Carboniferous fusulinids in a coastal section near Pendueles (Asturias, Spain). Leidse Geologische Mededelingen, 52:193-241.

Villa, E. 1995. Fusulinaceos carboníferos del este de Asturias (N de España). Biostratigraphie du Paléozoïque, Université Claude Bernard-Lyon I, 13:1-261.

von Möller, V. 1878. Die spiral-gewundenen Foraminiferen des russischen Kohlenkalks. Mémoires de l'Académie Impériale des Sciences de St Pétersbourg, 7th Series, 25:1-147.

Wang, K.L. 1987. The Lower Carboniferous foraminifer assemblage zones in South China, p. 346-347. In (editor unknown), 11th International Congress of Carboniferous Stratigraphy and Geology, Abstracts of Papers (II) Symposiums 1-11 and Miscellaneous. (publisher unknown), Beijing.

Wang, L. 1981. Some new species of fusulinids from the Carboniferous-Permian of Anhui, China. Acta Paleontologica Sinica, 20:127-137. (In Chinese with English abstract)

Wang, Y.J., Yuan, X.Q., and Geng, G.C. 1992. A new advance of Carboniferous fusulinid study and preliminary exploration of the paleogeography in the Ordos Basin. Acta Micropalaeontologica Sinica, 9:127-150. (In Chinese with English abstract)

Watanabe, K. 1973. Profusulinella assemblage in the Omi limestone, Niigata Prefecture, Central Japan (studies of Carboniferous fusulinacean of Omi, part I). Transactions and Proceedings Paleontological Society Japan, New Series, 92:371-394.

Wedekind, P.R. 1937. Einführung in die Grundlagen der historischen Geologie. Band II. Mikrobiostratigraphie die Korallen und Foraminiferenzeit. Ferdinand Enke, Stuttgart.

Zhang, L. and Rui, L. 1980. Fusulinids from the Binhai Xian, northern Jiangsu. Acta Paleontologica Sinica, 19(4):321-326, 357-358. (In Chinese with English abstract)

Zhao, Z.X., Han, J.X., and Wang, Z.G. 1984. The Carboniferous Strata and Its Fauna from Southwestern Margin of Tarim Basin in Xinjiang. Geological Publishing House, Beijing. (In Chinese) 